\title{
Distribution of immunocompetent cells in the bronchial wall of clinically healthy subjects showing bronchial hyperresponsiveness
}

\author{
C Power, S Sreenan, B Hurson, C Burke, L W Poulter
}

\begin{abstract}
Background-Nearly all asthmatic subjects show bronchial hyperresponsiveness, in that the provocative concentration of histamine reducing forced expiratory volume in one second $\left(\mathrm{FEV}_{1}\right)$ by $20 \%\left(\mathrm{PC}_{20} \mathrm{FEV}_{1}\right)$ is $\leqslant 8 \mathrm{mg} / \mathrm{ml}$ histamine, and have underlying chronic inflammation of the bronchial wall mediated by $T$ cells. The possible cause and effect relationship between these phenomena remains an enigma. As a proportion of clinically healthy subjects show bronchial hyperresponsiveness, this study was undertaken to determine whether they also show evidence of bronchial inflammation.
\end{abstract}

Methods-Bronchial biopsy specimens were obtained from 27 clinically healthy subjects with no history of lung disease. Samples were taken perioperatively before elective knee arthroscopy for sports injuries. Specimens were frozen and cryostat sections analysed immunocytochemically with monoclonal antibodies to identify the presence of $T$ lymphocytes, antigen presenting cells, and the expression of HLA-DR. Double immunofluorescence studies were performed with monoclonal antibodies RFD1 and RFD7 to show the relative proportions of RFD1 + RFD7- antigen presenting cells, RFD1 - RFD7 + mature phagocytes, and RFD1+ RFD7+ suppressor macrophages. Histological stains were performed to show the presence of eosinophils and mast cells. Three to four weeks after bronchoscopy spirometry was performed on these subjects to record $F E V_{1}$, forced vital capacity (FVC), FEV $/$ IFVC, and forced expiratory flow between $25 \%$ and $75 \%$ of vital capacity $\left(\right.$ FEF $\left._{25-75}\right)$. Bronchial hyperreactivity was recorded by determining $\mathrm{PC}_{20} \mathrm{FEV}_{1}$ to histamine.

Results-Nine of the 27 subjects showed bronchial hyperresponsiveness as defined by a $\mathrm{PC}_{20} \mathrm{FEV}_{1}$ of $\leqslant 8 \mathrm{mg} / \mathrm{ml}$ histamine. Segregated subjects with and without bronchial hyperresponsiveness showed no difference in spirometric results. Immunohistological analysis showed no evidence of inflammation in either group. Numbers of $T$ cells, eosinophils, and mast cells were the same in both groups as was the expression of HLA-DR antigen. No neutrophils were observed in any tissues. Interestingly, reduced numbers of macrophages with the phenotype of antigen presenting cells (monoclonal antibodies RFD1+ RFD7-) were recorded in the subjects with bronchial hyperresponsiveness, who also had a significant increase in the proportion of RFD1 + RFD7+ suppressor macrophages.

Conclusions-Up to $30 \%$ of selected clinically healthy subjects may have a $\mathrm{PC}_{20} \mathrm{FEV}_{1}$ of $\leqslant 8 \mathrm{mg} / \mathrm{ml}$ histamine. This physiological trait can exist in the absence of bronchial inflammation. This suggests that bronchial hyperresponsiveness as currently defined is not dependent on immunopathological changes in the bronchial wall and does not necessarily promote even subclinical inflammation.

(Thorax 1993;48:1125-1129)

Measurement of bronchial reactivity to graded doses of histamine or other stimuli is routinely used to measure bronchial hyperresponsiveness. ${ }^{1}$ Since this method was described by Cockcroft et al in $1977^{2}$ the measurement of $\mathrm{PC}_{20} \mathrm{FEV}_{1}$ has been shown to be a valuable variable for monitoring bronchial physiological reactivity, particularly in asthma. Although not specific for asthma, nearly all asthmatic subjects show bronchial hyperresponsiveness, which is currently defined as a $\mathrm{PC}_{20} \mathrm{FEV}_{1}$ of $\leqslant 8 \mathrm{mg} / \mathrm{ml}$ histamine, ${ }^{3}$ and changes in this variable reflect overall clinical change-for example, after steroid treatment.

Investigations of the immunopathology of the bronchial wall in asthmatic subjects have shown the presence of a chronic peribronchial inflammation characterised by accumulations of $T$ cells, antigen presenting cells, and macrophages. ${ }^{5}$ The increased expression of the CD45RO antigen on the $T$ cells and the increased expression of HLA-DR molecules on the inflammatory cells and the bronchial epithelium that is associated with this $T$ cell dominated inflarnmation suggest an active acquired cell mediated immune response. ${ }^{5}$ As with the physiological index of bron- 
chial hyperresponsiveness, this inflammatory picture is seen in asthmatic subjects even without acute symptoms. ${ }^{6}$ Measurements of HLA-DR expression in bronchial biopsy specimens of asthmatic subjects and of bronchial hyperresponsiveness in the same patients showed a strong correlation between the immunopathology and pathophysiology. ${ }^{5}$ Furthermore, efficacious treatment with inhaled corticosteroids caused concurrent improvement in bronchial hyperresponsiveness and inflammation. ${ }^{7}$ These results raise the possibility of a cause and effect relation between bronchial hyperresponsiveness and bronchial inflammation. The $\mathrm{T}$ cell mediated inflammation in the bronchial wall of asthmatic subjects is present in patients whose condition is stable, it does not necessarily cause clinical symptoms, ${ }^{56}$ and a proportion of clinically healthy subjects show bronchial hyperresponsiveness. ${ }^{8}$ We therefore studied clinically healthy subjects to determine whether evidence of bronchial inflammation could be found in non-asthmatic subjects showing bronchial hyperresponsiveness.

\section{Methods}

SUBJECTS

Twenty seven subjects ( 25 men, two women, age range 21-41) listed for elective arthroscopy were recruited from a sports injury clinic. None of these subjects had asthma or any nasal symptoms as determined from a detailed questionnaire and by normal baseline spirometric results on the day of surgery. None had had any viral infection during the two previous months and none had ever consulted a physician for any lung problem. Eight subjects were smokers and eight were atopic when tested with a panel of eight commercial allergen preparations by skin prick testing. All consented to perioperative bronchoscopy while undergoing knee arthroscopy and the study had the approval of the ethics committee of the James Connolly Memorial Hospital.

Biopsy specimens were taken during January and February and subsequent lung function tests performed during February and March.

\section{BRONCHOSCOPY}

Anaesthesia was induced with intravenous thiopentone 3-5 mg/kg and maintained with a mixture of oxygen, nitrous oxide, and enflurane. Subjects were intubated with a disposable size 9 endotracheal tube. Intubating conditions were achieved with suxamethonium $1 \mathrm{mg} / \mathrm{kg}$ and perioperative muscle relaxation was maintained with vecuronium titrated to effect. Perioperative analgesia was given as fentanyl $1.0-1.5 \mu \mathrm{g} / \mathrm{kg}$. Standard monitoring included electrocardiography, blood pressure using an automated cuff, and pulse oximetry. Under the supervision of the anaesthetist a fibreoptic bronchoscope (Olympus BF10) was passed through the endotracheal tube into the trachea. Endobronchial biopsy specimens were removed from adjacent to the right upper lobe carina under direct vision using spiked cup forceps (Olympus FB22C).

\section{LUNG FUNCTION}

Three to four weeks after bronchoscopy lung 걱 function was recorded. Baseline spirometry was performed with a computerised Gould. 2400 system. The best of three technically $\overrightarrow{\vec{F}}$ acceptable forced expiratory manoeuvres was recorded and the forced expiratory volume in $\frac{}{\sigma}$ one second $\left(\mathrm{FEV}_{1}\right)$, forced vital capacity $\frac{\bar{\sigma}}{\mathrm{s}}$ (FVC), and forced expiratory flow between $\widetilde{\Phi}$ $25 \%$ and $75 \%$ of vital capacity $\left(\mathrm{FEF}_{25-75}\right)$ recorded. A standard bronchial provocation protocol was performed one hour after base-. line studies were completed. ${ }^{2}$ After inhalation $\vec{\omega}$ of nebulised saline control solution, nebulised $\stackrel{\circ}{\circ}$ buffered histamine phosphate was inhaled for $\vec{x}$ two minutes through a face mask using a nebuliser driven by oxygen at $7 \mathrm{l} / \mathrm{min}$. Spirometric results were recorded at $30 \mathrm{~s}$ and $90 \mathrm{~s}$ and subsequently every $60 \mathrm{~s}$ after each $\vec{N}$ dose until $\mathrm{FEV}_{1}$ fell by $20 \%$, or if $\mathrm{FEV}_{1}$ value failed to fall the next strength of histamine 3 was given when the $\mathrm{FEV}_{1}$ returned towards $\vec{Z}$ baseline. The initial concentration of hista-O mine was $0.03 \mathrm{mg} / \mathrm{ml}$ and this was doubled at successive stages until a concentration of $16 \bar{\Phi}^{\circ}$ $\mathrm{mg} / \mathrm{ml}$ was used. The provocative concentration of histamine to reduce $\mathrm{FEV}_{1}$ by $20 \% \overrightarrow{0}$ $\left(\mathrm{PC}_{20} \mathrm{FEV}_{1}\right)$ was calculated from the dose-. response curve. To check reproducibility of $\square$ the $\mathrm{PC}_{20} \mathrm{FEV}_{1}$ measurements a further six normal volunteers (same criteria as selectedō orthopaedic patients) underwent three procedures to measure bronchial reactivity (same methods as described above) over one month. $\overrightarrow{0}$ This study was conducted to control the design of the original study, in which spirometric and bronchial hyperresponsiveness: studies were performed one month after $\overrightarrow{\widehat{\sigma}}$ bronchoscopy for logistical reasons.

\section{PREPARATION OF BIOPSY SPECIMENS}

The endobronchial biopsies were placed in optimum cutting temperature medium (BDH, Poole) on small cork discs and frozeno in isopentane cooled in a bath of liquid nitro- $>$ gen. The frozen tissues were stored in liquid으․ nitrogen for not more than one month. N Sections ( $6 \mu \mathrm{m}$ thick) were cut on a cryostat maintained at $-25^{\circ} \mathrm{C}$ and transferred to poly-L-lysine coated slides. These were airw dried, fixed in a mixture of chloroform and acetone (1:1), wrapped in cling film, and stored at $-20^{\circ} \mathrm{C}$ until use. At least $40 \mathrm{sec}-\stackrel{\Phi}{\oplus}$ tions were cut from each biopsy specimen.

\section{HISTOLOGY}

Sections from all biopsy specimens were stained with haematoxylin and eosin to show structure and with $0.1 \%$ toluidine blue to show mast cells. All these slides were examined by two of us (CP and LWP).

\section{IMMUNOHISTOLOGY}

Indirect immunoperoxidase methods were used to reveal specific cell types in the tissues. ${ }^{9} \mathrm{~T}$ lymphocytes were identified by using a cocktail of monoclonal antibodies 
CD2, CD5, and CD8 ( $\mathrm{T}$ mix); primed memory $T$ cells by using monoclonal antibody $\mathrm{CD} 45 \mathrm{RO}^{10}$; and antigen presenting cells by using monoclonal antibody RFD1. ${ }^{11}$ The distribution of these cells was measured using an image analyser (Seescan Cambridge), with which the area of framed fields in the sections (three per slide) were point counted as positive cells. ${ }^{12}$ From each set of sections two were selected at random for each test. Both were examined visually. Representative areas were then selected for measurement with the image analyser. In all sections from all biopsy specimens the variability between selected areas of any one specimen was far less than the variability between specimens. All results given thus quote the range throughout the group (thus reflecting the greatest variability seen). In each measurement the number of cells counted was divided by the area of framed tissue to obtain a figure representing the number of cells per $10^{4} \mu \mathrm{m}^{2}$. HLA-DR expression was recorded as relative optical density of the reaction product measured with the image analyser. ${ }^{12}$ Ten readings of relative absorption were taken from random areas of the lamina propria within a layer under the epithelium that was 10 cells deep. As with the cell counts the variability within the group was far greater than that within a single specimen. Thus ranges within groups are quoted in the results. Proportions of macrophage subsets were determined by double immunofluorescence methods ${ }^{13}$ in which monoclonal antibodies RFD1 and RFD7 were used in combination. By using two immunoglobulin class specific reagents conjugated to fluorescein isothiocyanate and tetramethyl rhodamine isothiocyanate as a combined second layer the relative proportions of RFD1 + RFD7- (antigen presenting cells fluorescing green), RFD1- RFD7+ (phagocytes fluorescing red), and RFD1+ RFD7+ (suppressor cells fluorescing red and green) could be determined. ${ }^{14}$ Colour photographs were taken of all areas and the proportion of cell subsets counted from these photographs. In all cases negative controls were performed omitting the specific monoclonal antibodies, and positive reagent controls were performed on sections of human palatine tonsil.

\section{STATISTICS}

Results are expressed as medians and ranges for each group. Data were analysed using the non-parametric Wilcoxon signed rank test.

Historical data from asthmatic subjects were also documented. However, this study was not designed to compare normal values with values in asthmatic subjects, so no asthmatic samples were analysed within this investigation. The figures for patients with diagnosed asthma are quoted purely for comparison.

\section{Results}

SPIROMETRIC RESULTS AND BRONCHIAL REACTIVITY

Spirometric results were normal in the 27 subjects biopsied. The median (range) \% predicted $\mathrm{FEV}_{1}$ was $100 \%$ (67-129\%), FVC was $103 \%(71-129 \%)$, and $\mathrm{FEF}_{25-75}$ was $97 \%$ (57-127\%). Median bronchial reactivity to histamine was also normal $(12.5 \mathrm{mg} / \mathrm{ml})$, although a broad range was seen including nine subjects who recorded a $\mathrm{PC}_{20} \mathrm{FEV}_{1}$ of $8 \mathrm{mg} / \mathrm{ml}$ or less. The 27 subjects were thus segregated into two groups on the basis of bronchial hyperresponsiveness. Nine patients responded to $8 \mathrm{mg} / \mathrm{ml}$ or less of histamine (median (range) $\mathrm{PC}_{20} \mathrm{FEV}_{1} 5.6(2-8 \mathrm{mg} / \mathrm{ml})$ and were defined as having bronchial hyperresponsiveness, and the other 18 had a median value of $19.7(2.4-36) \mathrm{mg} / \mathrm{ml}$ $(p<0.001)$ and were defined as not having bronchial hyperresponsiveness. The spirometric values recorded in the two groups showed no significant difference. There were four smokers in each group, three atopic subjects in the group showing no bronchial hyperresponsiveness, and five atopic subjects in the group showing bronchial hyperresponsiveness. None of the physiological or immunohistological parameters studied discriminated between these subjects.

\section{REPRODUCIBILITY}

To determine whether $\mathrm{PC}_{20} \mathrm{FEV}_{1}$ readings showed significant variability over a period of four weeks a group of six normal volunteers underwent repeat analysis for histamine reactivity. In four of the six subjects no significant variability occurred over this period. In two cases a doubling dilution variation was recorded (table 1), but in no case did any subject show a shift in bronchial hyperresponsiveness over this time to abnormal values. The subjects with a $\mathrm{PC}_{20} \mathrm{FEV}_{1}$ of $\leqslant 8 \mathrm{mg} / \mathrm{ml}$ remained stable at this level over the three repeated analyses (table 1 ).

\section{HISTOLOGY}

Haematoxylin and eosin staining of all biopsy specimens showed normal histology. No neutrophils were seen in any specimen. No thickening of the basement membrane was seen. The epithelium itself was disrupted in many specimens and occasionally torn off. This was taken to be artefactual, resulting from the freezing and cryostat sectioning of such small tissue samples. No evidence of inflammation was present. Small numbers of eosinophils, up to 10 per section, were observed but no difference was detected between subjects with and without bronchial hyperresponsiveness. Similarly, toluidine blue staining showed very

Table 1 Reproducibility of $P_{20} F E V_{1}$ ( $m g / m l$ histamine) in clinically healthy subjects

\begin{tabular}{lccc}
\hline Case no & Baseline & Two weeks & Four weeks \\
\hline 1 & $3 \cdot 8$ & $4 \cdot 7$ & $3 \cdot 2$ \\
2 & 20 & $12 \cdot 6$ & $>16^{\star}$ \\
3 & $3 \cdot 2$ & $2 \cdot 8$ & $6 \cdot 3$ \\
4 & $22 \cdot 9$ & $25 \cdot 1$ & $12 \cdot 6$ \\
5 & $8 \cdot 7$ & 20 & $25 \cdot 1$ \\
6 & $26 \cdot 3$ & $20 \cdot 9$ & $25 \cdot 1$ \\
\hline
\end{tabular}

${ }^{\star}$ Regression curve too flat to derive accurate figure. 
Table 2 Immunohistological analysis in clinically healthy subjects with and without bronchial hyperresponsiveness. Values are medians (ranges)

\begin{tabular}{|c|c|c|c|}
\hline Group & $\begin{array}{l}T \text { cells } \\
\left(n o / 10^{4} \mu m^{2}\right)\end{array}$ & $\begin{array}{l}R F D 1+\text { cells } \\
\left(n o / 10^{4} \mu m^{2}\right)\end{array}$ & $\begin{array}{l}H L A-D R \\
\text { (relative optical density) }\end{array}$ \\
\hline \multicolumn{4}{|c|}{ Bronchial hyperresponsiveness: } \\
\hline Present $(n=9)$ & $0 \cdot 2 \quad(0-3 \cdot 3)$ & $0.1 \quad(0-0.69)$ & $0.04(0-0.04)$ \\
\hline Absent $(n=18)$ & $0.56(0-1.2)$ & $0.34(0-2 \cdot 8)$ & $0.06(0-0.17)$ \\
\hline $\mathrm{p}$ value & NS & $<0.05$ & NS \\
\hline
\end{tabular}

Table 3 Proportions of macrophage subsets in 14 clinically healthy subjects and according to bronchial hyperresponsiveness *

\begin{tabular}{llll}
\hline Group & $R F D 1+$ & $R F D 7+$ & $R F D 1+R F D 7+$ \\
\hline Total (n= 14) & $11(3-19)$ & $44(17-65)$ & $46(27-75)$ \\
Bronchial hyperresponsiveness: & & & \\
Present $(\mathrm{n}=5)$ & $7(3-13)$ & $30(17-42)$ & $64(48-75)$ \\
Absent (n=9) & $11(4-19)$ & $54(41-65)$ & $34(27-44)$ \\
p valuef & NS & $<0.05$ & $<0.001$ \\
\hline
\end{tabular}

^In each case median (range) of all positive cells with specific phenotype is given as a percentage:

$$
\frac{\text { Specific phenotype }}{((\text { RFD1+) }+(\text { RFD7+ })+(\text { RFD1+ RFD7+ }))} \times 100
$$

†Comparing those with bronchial hyperresponsiveness with those without.

small numbers (1-3 per section) of mast cells in all samples irrespective of bronchial hyperresponsiveness.

Frozen tissue and sections are, however, inappropriate to study these granulocytes, which are best preserved by better fixation and embedding. Differences in these populations may thus exist, which were not detectable in this study (see discussion).

\section{IMMUNOHISTOLOGY}

Immunohistological studies of bronchial biopsy specimens failed to detect any difference between subjects with and without bronchial hyperresponsiveness in terms of the numbers and distribution of $T$ cells and the expression of HLA-DR (table 2). The numbers of RFD1 + macrophage-like cells were, however, significantly reduced in specimens taken from subjects with bronchial hyperresponsiveness. All results (irrespective of bronchial hyperresponsiveness) were 5-10 fold lower than previous data obtained from asthmatic subjects in whom the median figures for T cells, D1+ cells, and DR expression were $8.9,2 \cdot 2$, and 1.6 respectively. ${ }^{?}$

In 14 subjects immunofluorescence studies were performed with a combination of the monoclonal antibodies RFD1 and RFD7 to discriminate subtypes of macrophages. The proportions of RFD7 + RFD1+ suppressor cells were significantly increased in the group with bronchial hyperresponsiveness (table 3). This increase occurred at the expense of the RFD7 + RFD1- population, whose proportion was significantly reduced.

\section{Discussion}

Our study of 27 clinically healthy subjects with no history of any clinically significant lung disease shows that up to $30 \%$ of this population were bronchially hyperresponsive as defined by a $P_{20} F_{E V}$ of $\leqslant 8 \mathrm{mg} / \mathrm{ml}$ histamine. As all these subjects regularly participated in sporting activities they may be considered a selected population, and our results do not necessarily indicate the prevalence of bronchial hyperresponsivess in the general population.

Nevertheless, the total absence of any evidence of bronchial inflammation in the subjects showing bronchial hyperresponsiveness suggests that bronchial hyperresponsiveness is not dependent on bronchial inflammation. Furthermore, the presence of bronchial hyperresponsiveness need not in itself cause any inflammatory change in the bronchial wall. Interestingly, even the subject who had abnormal spirometric results (67\% predicted $\mathrm{FEV}_{1}$ ) showed no bronchial hyperreactivity or any evidence of airway inflammation.

Although bronchial hyperresponsiveness has been described as a cardinal feature of asthma, ${ }^{3}$ it is not specific for this disease. ${ }^{15}$ Indeed, bronchial hyperresponsiveness defined as an exaggerated response to histamine inhalation may be found in a proportion of the healthy, non-asthmatic population. ${ }^{2}$ The accepted cut off point of $8 \mathrm{mg} / \mathrm{ml} \mathrm{hista-}$ mine may be too high. ${ }^{16}$ Our results support this and suggest that the term bronchial hyperresponsiveness may need to be redefined. It is notable that two of the six subjects used to check reproducibility of results in the lung function laboratory consistently responded to concentrations of histamine lower than $8 \mathrm{mg} / \mathrm{ml}$. Hyperresponsiveness in any given subject might therefore be identified only when a change from baseline values is seen.

Interestingly, the difference in bronchial hyperresponsiveness that segregated the original group of 27 subjects existed in the absence of any difference in spirometric values between the two groups. This observation supports recent data showing that bronchial hyperresponsiveness and spirometry show different kinetics of recovery in patients with acute asthma. ${ }^{17}$ As significant correlations have been observed between bronchial hyperresponsiveness and inflammation in asthmatic patients, ${ }^{5}$ how do the healthy subjects in our study remain clinically normal and show no evidence of bronchial inflammation in the face of an apparent physiological defect? One possible clue emerges from the observation that the proportion of cells with the phenotype of suppressor macrophages is raised in these subjects. As previous studies have identified a unique balance of macrophage subsets at mucosal surfaces, ${ }^{14}$ increases in this putative suppressor population may reflect a response of the local immunological network to raised bronchial hyperresponsiveness that is aimed at further suppressing acquired $\mathrm{T}$ cell reactivity in the bronchial wall and thus reducing the risk of inflammation. This possibility is under further investigation. Other possibilities, such as changes in the local eosinophil population, which may be associated with bronchial hyperresponsiveness, ${ }^{18}$ clearly exist. Our study shows, however, that bronchial hyperresponsiveness can exist in the absence of any evidence of $T$ cell mediated inflammation in the bronchial wall. 
This work was supported by the Frank Peacock fellowship from the Royal College of Physicians of London to LW. CB is supported by the Royal College of Surgeons of Ireland. We acknowledge the support of the Eastern Health Board, Dublin.

1 Hargreave FE, Ryan G, Thomson NC, O'Byrne PN, Latimer $\mathrm{K}$, Juniper $\mathrm{EF}$, et al. Bronchial responsiveness to histamine or methacholine in asthma: measurement and clinical significance. $\mathcal{F}$ Allergy Clin Immunol 1981; 68:347-55.

2 Cockcroft DW, Killian DN, Mellon JA, Hargreave FE Bronchial reactivity to inhaled histamine: a method and clinical survey: Clin Allergy 1977;7:235-43.

3 Woolcock AJ. Asthma. In: Murray JF, Nadal JA. Textbook of respiratory medicine. Philadelphia: WB Saunders, 1988:1030-68.

4 Woolcock AJ, Yan K, Salome CM. Effect of therapy on bronchial hyperresponsiveness in the long-term management of asthma. Clin Allergy 1988;18:165-76.

5 Poulter LW, Power C, Burke C. The relationship between bronchial immunopathology and hyperresponsiveness in asthma. Eur Respir f 1990;3:792-9.

6 Kay AB, Corrigan CJ, Frew AJ. The role of cellular immunity in asthma. Eur Respir $\mathcal{F} 1991 ; 4$ (Suppl 13): 105-12.

7 Burke C, Power C, Norris A, Schmekel B, Condez A, Poulter LW. Lung function and immunopathological changes of inhaled corticosteroid therapy in asthma. Eur Respir f 1992;5:73-9.

8 Sparrow D, Weiss ST. Airway responsiveness and atopy in the development of chronic lung disease. New York: Raven, 1989:3.
9 Lapa E, Silva JR, Jones A, Cole PJ, Poulter LW. The immunological component of the cellular inflammatory infiltrate in bronchiectasis. Thorax 1989;44:668.

10 Akbar A, Terry L, Timms A, Beverley PCL, Janossy G. Loss of CD45R and gain of UCHL1 reactivity is a feature of primed T-cells. $\mathcal{f}$ Immunol 1988;140:1-8.

11 Poulter LW, Campbell DA, Munro C, Janossy G. Discrimination of human macrophages and dendritic cells using monoclonal antibodies. Scand $\mathcal{f}$ Immunol 1986;24:351-7.

12 Poulter LW, Norris A, Power C, Condez A, Barnes H, Schmekel B, Burke C. T cell dominated inflammatory reactions in the bronchioles of asymptomatic asthmatics are also present in the nasal mucosa. Postgrad Med $\mathcal{F}$ 1991;67:747-53.

13 Janossy G, Bofill M, Poulter LW. Two colour immunofluorescence analysis of the lymphoid system with monoclonal antibodies. In: Polak J, Van Noorden S. Immunocytochemistry today. Bristol: Wright, 1986:438

14 Hutter C, Poulter LW. The balance of macrophage subsets may be customised at mucosal surfaces. FEMS Microbiol Immunol 1992;105:309-16.

15 Boushey HA, Holtzman NJ, Sheller JR, Nadel JA. Bronchial hyperresponsiveness. Am Rev Respir Dis 1980; 121:389-413.

16 Cockcroft DW. Bronchial hyperresponsiveness: In: Mygind N, Pipkorn U, Dahl R, Rhinitis and asthma. Copenhagen: Munksgaard, 1990:172-87.

17 Whyte MKB, Chondry NB, Ind PW. Bronchial hyperresponsiveness in patients recovering from acute severe asthma. Respir Med 1993;87:29-35.

18 Wardlaw AJ, Dunnette S, Gleich GJ, Collins JV, Kay AB. Eosinophils and mast cells in bronchoalveolar lavage in subjects with mild asthma. Am Rev Respir Dis 1988; 137:62-9. 